Kuchar Iga, Kościelska Oktawia, Kędziora-Kornatowska Kornelia. Impact of otosclerosis symptoms on patients quality of life before and after surgery - a literature review. Journal of Education, Health and Sport. 2020;10(8):419-427. eISSN 2391-8306. DOI http://dx.doi.org/10.12775/JEHS.2020.10.08.051

https://apcz.umk.pl/czasopisma/index.php/JEHS/article/view/JEHS.2020.10.08.051

https://zenodo.org/record/4008081

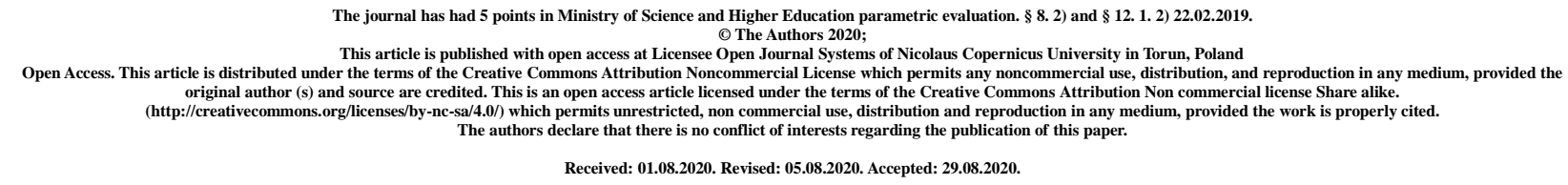

\title{
Impact of otosclerosis symptoms on patients quality of life before and after surgery - a literature review
}

\author{
Iga Kuchar, Oktawia Kościelska, Kornelia Kędziora-Kornatowska
}

Iga Kuchar ORCID: 0000-0002-3720-9882 email: igakuchar7@ gmail.com

Oktawia Kościelska ORCID: 0000-0001-7361-946X email: okoscielska@wp.pl

Kornelia Kędziora-Kornatowska ORCID: 0000-0003-4777-5252 email:

kornelia.kornatowska@cm.umk.pl

Katedra Geriatrii, Collegium Medicum im. Ludwika Rydygiera w Bydgoszczy Uniwersytetu Mikołaja Kopernika w Toruniu, Polska

Department of Geriatrics, Collegium Medicum im. Ludwik Rydygier in Bydgoszcz, Nicolaus Copernicus University in Toruń, Poland

\begin{abstract}
Otosclerosis is a chronic process that leads to hearing impairment and other onerous symptoms, such as tinnitus or dizziness. The following conclusions can be drawn from the analysis: they lead to problems in communication with the environment, as well as to different types of disorders of psychological nature, and this negatively affects the quality of life of patients. Despite the great progress in knowledge, the disease process cannot be completely stopped with otosclerosis. The most effective method of treatment is stapes surgery, which main goal is to improve speech hearing and understanding, as well as to reduce the accompanying symptoms. The greatest recognition among doctors collect stapedotomy surgery. The surgery may have unpleasant complications for some patients, but it is worth noting that in the majority of cases these problems disappear after a maximum of a few weeks. The aim of the study was to analyse previously published articles and other scientific literature on the impact of symptoms associated with otosclerosis on the quality of life of patients.
\end{abstract}


Due to the small number of relevant publications, the search time frame has not been limited. The search for the literature needed to write the article was conducted using the Google Scholar and PubMed scientific articles databases. The topics of the described works included: generally quality of life, what is the sense of hearing for a person, the effects of hearing loss on the patient's functioning, the impact of tinnitus on the patient's life, possible methods of treatment for otosclerosis, improved hearing after surgery, as well as possible postoperative complications and their impact on well-being of the patient.

Key words: otosclerosis, quality of life, surgical treatment

\section{INTRODUCTION}

Otosclerosis is a pathological process which inhibits the transmission of acoustic stimulus to the inner ear $[1,18,25]$.This results in progressive hearing impairment, and this in turn limitations in communication and related psychological, cognitive and emotional problems. The consequence is a reduction in the quality of life of patients $[2,3,5,10]$.

The most effective method of treatment is stapes surgery, the main goal of which is to improve hearing and speech understanding. A very important issue for patients in this method of treatment is the reduction of tinnitus, which is burdensome in everyday life and has a negative impact on the patients' well-being. Postoperative complications may occur, resulting in a deterioration of the quality of life $[1,2,13,19,25]$.

The disease results in calcification of the bone labyrinth. Then, abnormal spongy bone tissue develops, which in turn leads to immobilization of the stapes footplate in the oval window and atresia of the round window $[1,3,4,5,6]$. The reasons are not clear, but the scientific community speaks about genetic and immunological factors, hormonal disorders and viral infections [3,4]. It occurs 2 times more often in women than in men, mainly between the ages of 15-40, triggering or worsening during pregnancy and lactation $[1,4,5,8]$.

\section{OBJECTIVE OF THE WORK}

The aim of the study was to analyze the results of the studies carried out so far on the impact of symptoms accompanying otosclerosis on the quality of life of patients.

\section{MATERIAL AND METHODS}

The search for the literature needed to write a thesis was carried out using the databases of Google Scholar and PubMed scientific articles. When entering the combination of keywords: "otosclerosis", "quality of life" and "surgical treatment", we managed to search for 42 articles. The search timeframe was not limited as the number of relevant publications found was small. The criteria of selected articles were Polish and English.

\section{SYMPTOMS OF OTOSCLEROSIS}

The onset of the disease is usually overlooked. Conductive hearing loss (the most typical clinical picture) progresses slowly over many years, and there is no ear pain [5]. Hearing loss initially affects low and medium tones, and then high tones. Patients experience hearing impairment only at the threshold of 25-30 dB HL [1,4,5,6]. Patients have better hearing in noise, quiet speech and, at the same time, poorer pronunciation or lowering of sounds with low formants $[4,8]$. 
The next symptom is tinnitus, which is usually of low frequency. They can occur together with hearing loss or precede it by several years [6], and in total they occur in about $60 \%$ of all patients $[1,4,7]$.These are persistent sound impressions appearing in one or both ears in the absence of an external sound stimulus [4,7].

Other symptoms that are less common, but may still occur in patients, are dizziness and balance disorders. They lead to impaired fitness, may lead to falls, which in turn may be associated with serious injuries. They usually occur in about $30 \%$ of patients, additionally with a varying degree of severity $[1,15]$.

\section{SENSE OF HEARING AND QUALITY OF LIFE}

According to some scholars, the sense of hearing is the most important sense of man. Thanks to it, information from the environment flowing from every direction is constantly provided, and it facilitates spatial orientation and provides a sense of security. Acoustic impressions allow you to prepare for upcoming events, arouse interest and focus attention. Thanks to it, human has developed speech, and thanks to it, he is able to communicate, which is one of the most important categories of human life, the basic way of existence as a social being. Person can communicate with others, establish and maintain interpersonal contacts, express one's emotions, views and thoughts, as well as receive them from others $[10,16,18]$.

Many factors and human states come down to the quality of life, and these affect the subjective assessment of his own life. The fulfillment of all needs and values affects physical and mental health. The quality of life is also about the relationships between a person in society and the environment, and the degree to which he is independent [11].

\section{FUNCTIONING OF PATIENTS WITH AILERIES ACCOMPANYING OTOSCLEROSIS}

The research undertaken by the authors of the original works, as well as the findings of the authors cited in them $[10,11,13,17]$ show that hearing problems significantly reduce the quality of life by experiencing unpleasant situations related to it, effectively hinder communication with the environment and, consequently, the functioning of on a social, mental and professional level. Sometimes these are insurmountable barriers in everyday life: socializing, at work, which, as is well known, is necessary, for example, for material reasons, in dealing with matters in an office, shop, pharmacy, or during various forms of spending free time. Such barriers for people aged 15-40 are a huge loss $[9,10,11]$.

In the research article [10], the following conclusions were reached: over half of the respondents experienced unpleasant, stressful situations due to hearing problems; these situations and their frequency depend on the degree of hearing loss; stress affects relations with the environment; worse coping with challenges is a consequence of the increasing level of anxiety in a person with hearing loss; In these cases, stress is mainly demotivating, and additionally influences those people taking negative forms of releasing stress and tension.

People who suffer from hearing problems have to some extent limited possibilities of perceiving all cultural goods, such as television, cinema, theater or music. Another issue is the fact that they can hinder or completely block the possibility of performing certain professions. Obstacles in developing a passion or career can have a very negative impact on a person's self-esteem, mood and sense of belonging to social groups. Such persons feel helpless and ashamed and thus gradually withdraw from social life. In addition, people with hearing loss are a minority in the society, which may affect their stereotypes and the problem of marginalization. In their working lives, people with hearing impairment may feel worse. 
The results of the research show that the greater the degree of disability, the less benevolent and tolerant society is [10].

A consequence of the lack of support from the society may be that a person with a hearing impairment will become blocked and will not try to get help from specialists, and this will only result in the deterioration of the disorders that affect them [10, 11, 16, 19]. Lack of understanding and help can make such people even worse. For them, noticing hearing problems may come as a shock, because only then they realize how important it is in terms of communication [16].

Tinnitus is also a serious problem. In the own research of many authors of the original papers, the results show that people suffering from tinnitus may exhibit disturbances in the emotional sphere, which significantly affects their quality of life. The influence of the gender issue was noticed (in the author's own study, an increased level of anxiety was observed more often in younger women [9]). People experiencing highly annoying tinnitus more often experience more negative emotions, such as dissatisfaction with life, difficulties in achieving relaxation, anxiety, tension or stress [23] (it may even increase the volume and nuisance of tinnitus). Cognitive impairment is also emphasized in these people. Moreover, patients suffer from a number of other emotional and functional disorders, such as insomnia, anxiety disorders or attention disorders [7,9]. In their articles, the authors also cited previous studies by other authors and their collaborators, such as Attias, Kirsch, Scott and Lindberg, and compared them with their findings, for example, the Goldberg General Health Questionnaire of people with tinnitus showed that more than half of the respondents had high probability of emotional disorders [12]. On the basis of this questionnaire, McKenna et al. found that $45 \%$ of patients with tinnitus required psychological help (they also showed that $42 \%$ of patients suffering from otoneurological ailments needed this help, including, in addition to people with tinnitus, $27 \%$ of people with hearing impairment and $64 \%$ with dizziness) [20].

In the original study [21], it was estimated that $45 \%$ of the respondents suffered from depression on the basis of questionnaires designed to assess the impact of noise on the quality of life, with the vast majority of them suffering from mild depression, the rest - moderate. It has also been shown that in those patients with longer tinnitus ( 5 years), depression was more common.

The research of Sullivan et al. [22] confirms that tinnitus may significantly influence the appearance of depression. They studied a group of people suffering from tinnitus as well as a control group. In the group of healthy people the disease was observed in $7 \%$, while in the group of sick people in as much as $60 \%$.

On the basis of the above-mentioned research and after reading other studies mentioned in them, it can be safely assumed that all the above-mentioned ailments lead to general discomfort, high stress, embarrassment, lowered self-esteem, and consequently to disorganization of the personal life, isolation of the patient, withdrawal from social or professional life. This, in turn, may lead to the development of more serious mental disorders, such as depression, and even, in extreme cases, may lead to suicide attempts $[7,9,10,11,13,17,19]$. The problem in diagnosis is which of the symptoms have a more negative impact on the patient's life, because he himself is not able to objectively assess it $[7,9,11]$.

\section{TREATMENT}

Despite the great progress in knowledge, the disease process cannot be completely stopped in the case of otosclerosis. Surgical treatment makes it possible to regain hearing and return to work. The tinnitus is resolving or less severe. A hearing aid should be used in people who do not consent to surgery. Pharmacological treatment with sodium fluoride can also be used, but the results of its use are not unequivocal [19]. 
The most commonly used method is the surgical treatment of otosclerosis, which consists in improving the patient's hearing by restoring mobility within the oval window. In the case of bilateral hearing impairment, the worse hearing ear is always operated first, and if the results of audiometry of both ears are similar, the patient's subjective assessment of the hearing condition determines the order of operations. Contraindications to surgical treatment of otosclerosis include: active inflammation of the middle ear, perforation of the tympanic membrane, coexisting Ménière's disease, single hearing ear, sensorineural hearing impairment, pregnancy and poor general condition of the patient [25].

There are three types of surgical procedures: 1) stapedectomy - consists in the complete removal of the stapes with all or almost all of its plate and after the oval window is covered with a venous graft based on the prosthesis; 2) Stapedotomy - consists in leaving the stapes plate and making a small hole with a diameter of $0.6-0.8 \mathrm{~mm}$ in it, into which the end of the prosthesis is inserted; the whole should be sealed with pieces of connective tissue or fat; 3 ) platinectomy - about $1 / 3$ of the stapes footplate is removed, the prosthesis is sealed with connective tissue [19, 25].

\section{EVALUATION OF THE RESULTS OF SURGICAL TREATMENT OF OTOSCLEROSIS}

It is currently known that the most effective method of treating otosclerosis is the operation on the stapes. Stapedotomy is most often performed - the operation has been appreciated by many otosurgeons, it consists in removing the stapes supra structure and creating a small hole in the plate, into which a prosthesis is inserted suspended on a movable anvil [1,2,3,19,25].

Below are the results of otosclerosis surgery treatment studies (Gierek, Klimczak-Gołąb, 2007) [6] carried out in accordance with the criteria of the European Academy of Otology and Neuro-Otology (EAO-NO). The study included 1,527 people (1,165 women and 362 men) aged 11 to 73 who underwent stapedotomy. A change was observed - after one year of surgery, the mean value for air conduction from $55.2 \mathrm{~dB}$ to $27.55 \mathrm{~dB}$, and for bone conduction from $23.6 \mathrm{~dB}$ to $13.4 \mathrm{~dB}$. The average value of the cochlear reserve before the surgery was $31.7 \mathrm{~dB}$, and after $14.1 \mathrm{~dB}$. For individual frequencies: $500,1000,2000,4000 \mathrm{~Hz}$, the following values were obtained: $16 \mathrm{~dB}, 15$ $\mathrm{dB}, 13 \mathrm{~dB}, 13 \mathrm{~dB}$. The noise was resolved in $74 \%$ of operated patients and its intensity was not observed to be intensified after the operation.

According to the data from the analysis of results after surgery in otosclerosis, the vast majority of patients achieve a significant improvement in hearing as well as resolution or reduction of tinnitus [6].

Based on the original work (Miszka, Skarżyński, 2000) [6], the results of surgical treatment of a special group of patients will be presented, due to the high degree of risk associated with worse conditions for obtaining good results that satisfy the patient - advanced otosclerosis type C and D (classification according to Shambaugh type C- bone curve at 25-35 dB, type D- bone curve at a level below $36 \mathrm{~dB}$ ), it is accompanied by a cochlear reserve characteristic of full conductive deafness. The age of the patients ranged from 17 to 72 years of age. A typical stapedotomy was performed. One patient experienced a profuse leakage of peri-lymphatic fluid after partial plate fracture. In cases of advanced disease of type C and D, surgery may face significant technical difficulties, which is associated with the possible complications of the inner ear's efficiency. It is manifested in postoperative examination by lowering the bone curve to various degrees, including complete deafness. There is no such complication in the group of treated patients. The results of the operation are presented: bone curve elevation - no changes in 8 patients, $10 \mathrm{~dB}$ increase in 8 patients, $15 \mathrm{~dB}$ increase in 6 patients, $20 \mathrm{~dB}$ increase in 7 patients. Bone curve lifting is a very beneficial phenomenon for a patient with type $\mathrm{C}$ and $\mathrm{D}$ the advancement of otosclerosis. 
Closing or reducing the cochlear reserve allows the hearing to return to the level of social efficiency or increases the efficiency of apparatus. Cochlear reserve after surgery: full closure in 6 people, closure up to $10-15 \mathrm{~dB}$ in 13 , closure up to $20 \mathrm{~dB}$ in 10 . None of the patients had postoperative nystagmus, and the dizziness subsided after a few days. There were no symptoms of permanent damage to the vestibular organ and no increase in tinnitus. To sum up, surgical treatment of advanced otosclerosis does not cause permanent damage to the inner ear to the extent that its function eliminates, requires great operator skills and has a positive effect on the quality of life of the treated patients [15].

Referring to the latest study assessing the impact of stapedotomy on the quality of life of patients with otosclerosis [2], it is clear that stapes surgery has resulted in a significant improvement in the quality of life in most patients. After the surgery, ailments such as hearing loss and tinnitus were reduced. Improving the quality of life after stapedotomy is just as important as the effectiveness of the operation in terms of audiometric and audiological outcomes.

One of the methods used in the study were self-report questionnaires - Glasgow Benefit Inventory (GBI), Tinnitus Functional Index (TFI) and Abbreviated Profile for Hearing Aid Benefit (APHAB), which are a subjective tool for describing the patient's benefits in various areas of life after surgery. Analysing the individual GBI result, it was shown that 176 patients, i.e. $92 \%$ of all examined patients, obtained positive results, which proves the beneficial effect of the surgery on the quality of life. Only 11 patients, i.e. $6 \%$, assessed the impact of the surgery on the quality of life as negative. In subsequent questionnaires, it was noticed that there is an improvement in the quality of life in the case of subjective improvement in hearing and reduction of tinnitus. Each of the improvements was significant in improving the quality of life after stapedotomy. After their comparison, it was shown that the TFI change was the most significant in this case, i.e. the noise reduction brought about better effects than the actual improvement in hearing.

\section{POSTOPERATIVE COMPLICATIONS - PATIENT FUNCTIONING}

Stapes surgery in the treatment of otosclerosis is a very effective method, but it has complications that can occur in patients. However, it should be noted that these complications in the vast majority of cases disappear after a maximum of a few weeks.

Dizziness is one of the most common effects of surgery. They are temporary and usually disappear a few days after the operation. They arise as a result of the irritation of the labyrinth, the presence of a peri-lymphatic fistula or too long prosthesis [25]. If the prosthesis is too long, reoperations are performed to reduce its length. Patients often complain of ailments accompanying dizziness, such as headache, nausea, and balance disorders. This can limit the performance of one's duties at work, family and social life, reducing self-esteem. Constantly feeling it interferes with everyday functioning and reduces the quality of life to a greater or lesser extent. In a postoperative study conducted by a group of doctors [23], two patients who experienced dizziness a few months after the operation reported, after the stapes prosthesis was shortened, the dizziness disappeared. The risk of tinnitus in a group of patients who did not experience it before the surgery, however, in the vast majority of patients it disappears after a few days or weeks. In the study by Bast et al. [3] tinnitus occurred in only 1 patient after surgery and it resolved within 6 weeks. Rajati et al. [3] found tinnitus briefly in 2 out of 3 patients who did not report it before the surgery, but disappeared after a month. Tinnitus can be dangerous to the patient's mental state. They can contribute to depression and anxiety. People experiencing noise are less satisfied with life, have difficulty focusing, and have difficulty dividing attention. 
Therefore, it is important to reduce or reduce the intensity of tinnitus [13]. The next effect of the operation may be taste disturbances - they occur with varying frequency, are usually associated with damage or complete rupture of the eardrum, they resolve spontaneously within a few months at the latest [27]. The Mahendran study compared taste disturbance after ear surgery in two groups of patients: with a cut eardrum and with an intact eardrum. In the first group of patients, almost all of them experienced taste problems, and in the second group, about half. The severity of the drum string resulted in more severe symptoms and the dysgeusia was more common in these patients. The most common symptoms were: a metallic taste (34\%), numbness of the tongue $(24 \%)$, tingling of the tongue (13\%), a feeling of sweet taste in the mouth (11\%). Ciofalo et al. Studied 30 patients undergoing stapedotomy, in whom the tympanic cord had not been cut. For this purpose, paper strips impregnated with four concentrations of each flavour were used: sweet, sour, salty and bitter. Examination of the entire oral cavity showed a slight decrease in sensation that lasted up to 6 months after surgery. One month after surgery, the result on the operated side was below normal, but after 6 months it returned to normal values. A decrease in sensation was also observed on the non-operated side, but these values were within the normal range. Taste disturbances after a stapedotomy occur with varying frequency and usually disappear after a short time. They are more common in patients with a cut tympanic cord [27]. Disturbance in the reception of taste stimuli reduces the quality of life of patients, often contributing to the loss of pleasure in eating food. This can lead to food cessation, with very serious consequences. It also has a negative impact on the well-being of patients, through a huge irritation with the resulting phenomenon. In the long run it is very burdensome in normal functioning [4]. In addition to the above-mentioned postoperative complications in stapes surgery in the form of dizziness, tinnitus, and tearing of the tympanic cord causing taste disturbances, there may be other effects. Such as: balance disorders, floating stapes footplate, sensorineural hearing loss, the presence of a peri-lymphatic fistula. The following may also occur: palsy of the facial nerve, perforation of the tympanic membrane, necrosis of the appendix of the long anvil, removal of the prosthesis, and meningitis $[25,27,1]$.

\section{CONCLUSION}

Based on the above-mentioned studies, it can be concluded that any symptoms that occur in patients with otosclerosis before surgery, as well as possible complications that occur soon after surgery, negatively affect the quality of life of patients. Thanks to a successful stapes surgery, when the vast majority of patients report improvement in the form of reduction in hearing loss and tinnitus, the patient manages to free himself from other negative symptoms accompanying these ailments. Naturally, the patient's well-being improves and the patient's self-esteem increases, overall social and professional activity increases, and the quality of life increases. In most cases, all the unpleasant effects that caused negative thoughts were caused by the appearance of hearing disorders, and after the surgery, patients were able to free themselves from them, and this has a definitely positive impact on their quality of life.

\section{Conflict of Interest}

The authors do not report any financial or personal connections with other persons or organizations that could adversely affect the content of the publication and claim the right to this publication. 


\section{Literature}

1. Chodynicki S, Olszewska E: Otoskleroza. In: Śliwińska-Kowalska M (ed.): Audiologia kliniczna. $1^{\text {st }}$ ed., Mediton, Łódź 2005: 237-248.

2. Dziendziel B, Skarżyński H, Gos E et al.: Wpływ stapedotomii na jakość życia pacjentów z otosklerozą. Now Audiofonol 2019; 8(1): 45-52.

3. Dziendziel B, Skarżyński PH, Rajchel J et al.: Ocena częstości występowania i uciążliwości szumów usznych u pacjentów poddanych operacyjnemu leczeniu otosklerozy - przegląd piśmiennictwa. Now Audiofonol 2017; 6(2): 13-20.

4. Dżaman K, Pleskacz WA, Wałkanis A et al.: Ocena zmysłu smaku i węchu u pacjentów z polipami nosa. Otolaryngologia Polska 2007; Tom 61 Wyd. 5: 831-837.

5. Frankowska A: Jakość życia dzieci i młodzieży z wadą słuchu. Uniwersytet Medyczny im. Karola Marcinkowskiego w Poznaniu Wydział Nauk o Zdrowiu, Poznań 2014.

6. Gierek T, Klimczak-Gołąb L: Wyniki leczenia chirurgicznego otosklerozy - seria 1527 przypadków. Otolaryngologia 2007; 6(2): 110-114.

7. Hans-Georg Boenninghaus: Otorynolaryngologia, przekład Tatiana Gierek, Wyd. I, Springer PWN, Warszawa 1997: 132-135.

8. Hébert S, Lupienc S: The sound of stress: Blunted cortisol reactivity to psychosocial stress in tinnitus sufferers. Neuroscience Letters 2007; 138-142.

9. Jachimowska K: Komunikacyjne aspekty tekstów pisanych przez osoby z dysfunkcją słuchu. Wydawnictwo Uniwersytetu Łódzkiego, Łódź 2013.

10. Janieszewska M, Bernadetta Kulik T, Sztorc E et al.: Stress and coping with stress on the example of people with hearing loss. Pielęgniarstwo Polskie Nr 1 (59) 3/2016; 43-49.

11. Kałużny W, Durko T, Pajor A: Ocena wpływu szumów usznych na stan emocjonalny chorych na podstawie Kwestionariusza Ogólnego Stanu Zdrowia Goldberga. Otolaryngol Pol 2004; 58(4): 851-856.

12. Klaczak M, Majewicz P (eds.): Praca z dzieckiem z dysfunkcją słuchu. In: Diagnoza i rewalidaja indywidualna dziecka ze specjalnymi potrzebami edukacyjnymi. Wydawnictwo Naukowe Akademii Pedagogicznej, Kraków 2006: 57-79.

13. Kubińska A: Wybrane aspekty psychospołecznego funkcjonowania oraz skuteczność terapii poznawczo-behawioralnej u osób cierpiących z powodu szumów usznych. Nowa Audiofonologiaß 4(2), 2015: 53-57.

14. McKenna L, Hallam RS, Hinchcliffe R: The prevalence of psychological disturbance in neurootology outpatients. Clin Otolaryngol Allied Sci 1991; 16(5): 452-456.

15. Miszka K, Skarżyński H, Zawadzki R et al.: Stan ucha wewnętrznego po operacjach zaawansowanej otosklerozy. Audiofonologia Tom XVIII 2000: 181-185.

16. Pajor A, Józefowicz-Korczyńska M, Durko T et al.: Występowanie zaburzeń emocjonalnych u osób z szumami usznymi. Otorynolaryngologia 2009, 8(2): 86-92.

17. Pluta- Wilczyk A: Ocena wpływu aparatowania narządu słuchu na subiektywnie postrzeganą jakość życia w grupie osób po 60 r. ż. wykazujących średnie upośledzenie słuchu. Krakowska Akademia im. Andrzeja Frycza- Modrzewskiego, Wydział Lekarski i Nauk o Zdrowiu, Kraków 2018.

18. Potocka M, Mionskowski T, Kuczkowski J: Etiopatogeneza otosklerozy. For Med Rodz 2010; 281-285.

19. Pruszewicz A, Obrębowski A: Audiologia kliniczna. Zarys. Wydawnictwo Naukowe UMP, Poznań 2010: 366-369. 
20. Skarżyński H, Mrówka M, Młotkowska-Klimek P et al.: Stapedotomia u chorych z małą rezerwą słuchową. Audiofonologia 2003; XXIV 37-41.

21. Skarżyński H, Porowski M: Stapedotomia jako metoda z wyboru w leczeniu otosklerozy młodzieńczej. Audiofonologia 2006: 101-103.

22. Sullivan MD, Katon W, Dobie R et al.: Disabling tinnitus: association with affective disorder. Gen Hosp Psychiatr 1988; 10: 285-291.

23. Ścierski W, Namysłowski G, Czerwińska G et al.: Pooperacyjne zawroty głowy związane z nadmierną długością protezki strzemiączka - diagnostyka radiologiczna. Otolaryngologia Polska Tom 66 Wyd. 5., wrzesień-październik 2012: 363-367.

24. Świętek M, Świętek M, Magnuszewski Ł et al.: Zawroty głowy u starszych pacjentów problem interdyscyplinarny. Gerontologia Polska 2019; 27: 157-162.

25. Tomik J, Solowska B: Otoskleroza - etiologia, diagnostyka, leczenie. Neurolingwistyka Praktyczna 2017 nr 3: 9-17.

26. Witczak P, Olejniczak D, Skonieczna J: Ocena jakości życia przed i po protezowaniu narządu słuchu. Journal of Education, Health and Sport 6(9):712-723.

27. Wojciechowski M, Skarżyński PH: Zaburzenia smaku po zabiegu stapedotomii - przegląd piśmiennictwa. Now Audiofonol 2019; 8(1): 31-34.

28. Zielińska-Bliźniewska H, Olszewski J: Szumy uszne a depresja. Otolaryngol Pol 2009; 63 (7):

20-23. 